\title{
DIABETES AWARENESS AMONG PATIENT'S ATTENDANT VISITING IN TEACHING HOSPITAL OF EASTERN NEPAL
}

\author{
Ghimire $H B^{1^{*}}$, Parajuli $P^{2}, K C$ Heera ${ }^{3}$, Parajuli $S B^{4}$
}

\section{Affiliation}

1. Lecturer, Department of Internal Medicine, Birat Medical College \& Teaching Hospital, Morang, Nepal

2. MSc. Nursing, Biratnagar Aspatal Pvt. Ltd., Biratnagar, Morang, Nepal

3. College of Nursing, B. P. Koirala Institute of Health Sciences, Dharan, Nepal

4. Lecturer, Department of Community Medicine, Birat Medical College \& Teaching Hospital, Morang, Nepal

\section{ARTICLE INFO}

Article History

Received : 12 April, 2017

Accepted : 2 August, 2017

Published : 30 August, 2017

(c) Authors retain copyright and grant the journal right of first publication with the work simultaneously licensed under Creative Commons Attribution License CC - BY 4.0 that allows others to share the work with an acknowledgment of the work's authorship and initial publication in this journal.

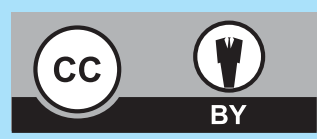

ORA33

\section{* Corresponding Author \\ Dr. Hridaya Bibhu Ghimire Lecturer}

Department of Internal Medicine

Birat Medical College \& Teaching Hospital, Morang, Nepal Email: hbghimire@hotmail.com

\section{Citation}

Ghimire HB, Parajuli P, Kc Heera, Parajuli SB. Diabetes Awareness Among Patient's Attendant Visiting in Teaching Hospital of Eastern Nepal. BJHS 2017;2 (2)3 : 211-214

\section{ABSTRACT \\ Introduction}

Diabetes is a prevalent non-communicable disease. It has increasing global trend. In Nepal, the prevalence of diabetes is also increasing. Awareness is vital to prevent and early diagnosis of diabetes.

\section{Objectives}

The objective of study was to assess the awareness of diabetes and its related factors.

\section{Methodology}

This was a hospital based cross sectional study. Total of 503 patient's attendant visiting teaching hospital of eastern Nepal from $1^{\text {st }}$ September to $30^{\text {th }}$ October 2016 were enrolled by using convenient sampling methods. Informed voluntary consent was obtained from each participants prior to data collection The collected data was entered into Microsoft excel and analysed by statistical package for social sciences (SPSS).

\section{Results}

Among 503 articipants, six out of 10 said that diabetes have complications related to kidney, heart and eyes. Seven out of 10 said diabetic should go for regular check-up of kidney, heart and eyes. Similar findings were reported on diabetic having higher chances of developing hypertension or dyslipidaemia. Literate participants had more awareness on diabetes and its associated factors than illiterate participants $(p<0.001)$. There was no significant association found on diabetes and its factors awareness with gender in all components except female participants were more aware about diabetes related complications than male.

\section{Conclusions}

Literate participants were aware on diabetes complication and its associated factors. However, participants were less aware on behaviour modification.

\section{KEY WORDS}

Awareness, Diabetes Melllitus, Teaching Hospital, Nepal 


\section{INTRODUCTION}

Type 2 diabetes mellitus and pre-diabetes condition is increasing rapidly among middle-aged and older adults. ${ }^{1}$ Among all the diseases measured in years lived with disability, type 2 diabetes mellitus has increased the most from 1990 to $2013 .{ }^{2}$ About $50 \%$ of those with diabetes remain undiagnosed. ${ }^{3}$ Community awareness on diabetes is the key step for early detection and prevention of diabetes and its complication. ${ }^{4}$ Type 2 diabetes can be prevented when people with increased risk for diabetes have their lifestyle modification., Increasing public awareness on diabetes could improve overall health of the society and reduce the risk of developing diabetes. ${ }^{7}$ For preventing type 2 diabetes, it is important to develop tools and strategies so that individuals at high risk could make lifestyle changes. ${ }^{8}$ This study was conducted to assess the diabetes awareness among patient's attendant visiting a teaching hospital in eastern Nepal.

\section{METHODOLOGY}

A hospital based cross-sectional study was conducted at Birat Medical College \& Teaching Hospital from $1^{\text {st }}$ September to $30^{\text {th }}$ October 2016. The participants were explained about the aim of the study. Participation was voluntary and those who were not willing to participate could withdraw anytime from the study. Only the patients' attendant willing to give a written consent were included for the study. Questions were pretested prior to data collection and necessary correction was made. The data were collected from 503 participants (patients' attendant) using pretested semi-structured questionnaires. Collected data were entered in Microsoft excel and analysed by statistical package for social sciences (SPSS), version 16. Data were presented in frequency, percentage, mean and standard deviation and Chi square test was used to find the association between variables.

\section{RESULTS}

A hospital based cross sectional study was conducted among 503 patient's attendant visiting teaching hospital of eastern Nepal. Among them both gender had equal proportion. The age of the participants was in the range from 15 to 83 years, with mean and standard deviation of $42.3 \pm 16$ years. Table 1 shows the basic socio-demography of study participants.

Table 1: Socio-demography of study population $(n=503)$

\begin{tabular}{|l|c|c|}
\hline Demographic profile & Male & Female \\
\hline Age (Mean \pm SD) & $43.88 \pm 15.92$ years & $40.63 \pm 15.94$ years \\
\hline Literate/illiterate & $114 / 138(45.2 \% / 54.8 \%)$ & $137 / 114(54.6 \% / 45.4 \%)$ \\
\hline
\end{tabular}

As shown in table 2, among the participants, $57.5 \%$ cited diabetes could lead to heart, eyes and kidney diseases. Almost $70 \%$ answered that people suffering from diabetes should go for regular check-up of kidney, heart and eyes. About $70 \%$ participants said that diabetic people could have higher chances of getting hypertension or dyslipidaemia than normal person. Among the participants, 39.8\% were not aware about normal salt intake in their diet and $43.9 \%$ were not aware on normal amount of fat intake in their diet. Only $3 \%$ participants were aware that regular daily exercise helps to prevent diabetes.

Table 2: Awareness on diabetes and related factors among the participants $(n=503)$

\begin{tabular}{|l|c|}
\hline \multicolumn{1}{|c|}{ Variables } & Yes (\%) \\
\hline $\begin{array}{l}\text { Diabetes have complications related to kidney, } \\
\text { heart and eyes }\end{array}$ & 57.5 \\
\hline $\begin{array}{l}\text { Diabetic should get regular check -up of kidney, } \\
\text { heart and eyes }\end{array}$ & 69.4 \\
\hline $\begin{array}{l}\text { Diabetic having higher chances of developing } \\
\text { hypertension or dyslipidaemia }\end{array}$ & 69.2 \\
\hline Aware on normal salt intake in their diet & 39.8 \\
\hline Aware on normal fat intake in their diet & 43.9 \\
\hline Aware on regular exercise & 3.0 \\
\hline
\end{tabular}

As shown in table 3, among 251 literate people, 97.6\% responded diabetes have complications related to kidney, heart and eyes, whereas among 252 illiterate people only $17.5 \%$ were aware of its complications. Literate participants were more aware on diabetes than illiterate and it was statistically significant $(p<0.001)$. Regarding whether diabetic should get regular check-up of kidney, heart and eyes, among 251 literate $98 \%$ and among 252 illiterate $40.9 \%$ correctly responded which was statistically significant

Table 3: Association between diabetes related awareness with literacy status.

\begin{tabular}{|c|c|c|c|c|c|}
\hline \multirow[b]{2}{*}{ Variables } & \multicolumn{2}{|c|}{ Literate } & \multicolumn{2}{|c|}{ Illiterate } & \multirow[b]{2}{*}{ P value } \\
\hline & Aware & $\begin{array}{l}\text { Not } \\
\text { aware }\end{array}$ & Aware & $\begin{array}{l}\text { Not } \\
\text { aware }\end{array}$ & \\
\hline $\begin{array}{l}\text { Diabetes have complications } \\
\text { related to kidney, heart and eyes }\end{array}$ & $\begin{array}{c}245 \\
(97.6 \%)\end{array}$ & $\begin{array}{l}6 \\
(2.4 \%)\end{array}$ & $\begin{array}{c}44 \\
(17.5 \%)\end{array}$ & $\begin{array}{c}208 \\
(82.5 \%)\end{array}$ & $<0.001^{*}$ \\
\hline $\begin{array}{l}\text { Diabetic should get regular check- } \\
\text { up of kidney, heart and eyes }\end{array}$ & $\begin{array}{l}246 \\
(98 \%)\end{array}$ & $(2.0 \%)$ & $\begin{array}{c}103 \\
(40.9 \%)\end{array}$ & $\begin{array}{c}149 \\
(59.1 \%)\end{array}$ & $<0.001^{*}$ \\
\hline $\begin{array}{l}\text { Diabetic having higher chances of } \\
\text { developing hypertension or } \\
\text { dyslipidaemia }\end{array}$ & $\begin{array}{c}245 \\
(97.6 \%)\end{array}$ & $\begin{array}{l}6 \\
(2.4 \%)\end{array}$ & $\begin{array}{c}103 \\
(40.9 \%)\end{array}$ & $\begin{array}{c}149 \\
(59.1 \%)\end{array}$ & $<0.001^{*}$ \\
\hline
\end{tabular}

*Significant 
$(p<0.001)$. When participants were asked whether diabetic have higher chances for developing hypertension or dyslipidaemia, among 251 literate 97.6\% and among 252 illiterate $40.9 \%$ were aware. A statistically significant association $(p<0.001)$ was shown with literate being more aware than illiterate. people need regular kidney, heart and eyes check-up compared to illiterate. Higher number of females cited that diabetes could lead to kidney, eyes and heart complications. This finding is supported by a study where participants with no formal education were found to have less awareness about diabetes and its associated factors compared with the educated group. ${ }^{13}$ Similarly, in a study, it was found that

Table 4: Association between diabetes related awareness with gender

\begin{tabular}{|c|c|c|c|c|c|}
\hline \multirow{2}{*}{ Variables } & \multicolumn{2}{|c|}{ Male } & \multicolumn{2}{|c|}{ Female } & \multirow{2}{*}{ P Value } \\
\hline & Aware & $\begin{array}{l}\text { Not } \\
\text { aware }\end{array}$ & Aware & $\begin{array}{c}\text { Not } \\
\text { aware }\end{array}$ & \\
\hline $\begin{array}{l}\text { Diabetes have complications related } \\
\text { to kidney, heart and eyes }\end{array}$ & $\begin{array}{c}134 \\
(53.2 \%)\end{array}$ & $\begin{array}{c}118 \\
(46.8 \%)\end{array}$ & $\begin{array}{c}155 \\
(61.8 \%)\end{array}$ & $\begin{array}{c}96 \\
(38.2 \%)\end{array}$ & $0.047^{*}$ \\
\hline $\begin{array}{l}\text { Diabetic should get regular check-up } \\
\text { of kidney, heart and eyes }\end{array}$ & $\begin{array}{c}163 \\
(64.7 \%)\end{array}$ & $\begin{array}{c}89 \\
(35.3 \%)\end{array}$ & $\begin{array}{c}186 \\
(74.1 \%)\end{array}$ & $\begin{array}{c}65 \\
(25.9 \%)\end{array}$ & 0.070 \\
\hline $\begin{array}{l}\text { Diabetic having higher chances } \\
\text { of developing hypertension or } \\
\text { dyslipidaemia }\end{array}$ & $\begin{array}{c}163 \\
(64.7 \%)\end{array}$ & $\begin{array}{c}89 \\
(35.3 \%)\end{array}$ & $\begin{array}{c}185 \\
(73.7 \%)\end{array}$ & $\begin{array}{c}66 \\
(26.3 \%)\end{array}$ & 0.088 \\
\hline
\end{tabular}

*Significant

Table 4 depict that among 252 male, 53.2\% responded diabetes have complications related to kidney, heart and eyes, whereas among 251 female 61.8\% were aware on above complications. Female participants were more aware than male which was statistical significant $(p<0.05)$. Regarding the knowledge for diabetic should get regular check-up of kidney, heart and eyes, among 252 male $64.7 \%$ were aware and among 251 female $74.1 \%$ were aware. Female had more awareness than male however; it was statistically not significant ( $p$ 0.070). Regarding diabetic having higher chances of developing hypertension or dyslipidaemia, among 252 male 64.7\% were aware and among 251 female $\mathbf{7 3 . 7 \%}$ were aware. Female had more awareness than male but it was not statistically significant (p 0.088).

\section{DISCUSSION}

In this study, almost six out of 10 participants were aware on the fact that diabetes will have complications related to kidney, heart and eyes, seven out of 10 were aware that diabetic should get regular check-up of kidney, heart and eyes. Similar number of people cited diabetes patients have higher chances of developing hypertension or dyslipidaemia. In a study it was reported that, knowledge of the visible complications (loss of eye-sight, poor wound healing) of diabetes appeared to be some what better than knowledge of other complications (kidney disease, heart disease, stroke). ${ }^{9}$ Similar studies in India, Kenya and Iran found little knowledge on diabetes and its complications. ${ }^{10-12}$

In this study, higher number of literate people were aware about diabetic complications and thought that diabetic diabetes awareness was low especially in participants with low education but in contrast to this study diabetes awareness was found to be low in women. ${ }^{14}$ In this study, it may be possible that literate people have heard about diabetes related complications from friends or have read in newspaper or any information booklets leading to higher level of knowledge about disease related problems. In this study, almost four out of 10 participants were aware on normal salt intake in their diet and similar number of people were aware on normal fat intake in their diet. Only three out of 100 participants were aware on regular exercise. According to World Health Organisation, by eliminating common risk factors, such as tobacco use, harmful use of alcohol, high salt intake, unhealthy diet, high sugar intake and physical inactivity, around $80 \%$ of heart disease, stroke, and type 2 diabetes and over a third of cancers could be prevented. ${ }^{15}$ As suggested by World Health Organisation, we need intervention earlier in common risk factors because this study found high risk behaviour for diabetes occurrence. It is possible to achieve significant reduction in high blood pressure; diabetes related complications such as stroke and cardiovascular disease by reducing salt intake in people with and without hypertension. ${ }^{16,17}$

\section{CONCLUSIONS}

This study gives general outline about people's awareness on diabetes and its associated factors. Literate people had significantly more awareness on diabetes and its associated factors. Therefore, we could say that literacy have role in awareness on diabetes. Gender difference have no role in awareness in diabetes and its factors. However, risk behaviour for diabetes was high in all participants. 


\section{RECOMMENDATION}

As literate participants had more awareness on diabetes and its factors than illiterate participants, we recommend more health awareness program to public.

\section{LIMITATIONS OF THE STUDY}

Information bias may hamper the generalisation of study findings. We recommend conducting educational

\section{REFERENCE}

1. Stene LC, Midthjell K, Jenum AK, Skeie S, Birkeland KI, Lund E, et al. Prevalence of diabetes mellitus in Norway. Tidsskr Nor Laegeforen. 2004 Jun 3;124(11):1511-4.

2. Global Burden of Disease Study 2013 Collaborators. Global, regional, and national incidence, prevalence, and years lived with disability for 301 acute and chronic diseases and injuries in 188 countries, 1990-2013: a systematic analysis for the Global Burden of Disease Study 2013. Lancet. 2015 Aug 22;386 (9995):743-800.

3. Harris MI, Eastman RC. Early detection of undiagnosed diabetes mellitus: A US perspective. Diabetes Metab Res Rev. 2000 Jul-Aug;16 (4):230-6.

4. Deshpande AD, Harris-Hayes M, Schootman M. Epidemiology of diabetes and diabetes-related complications. Phys Ther. 2008 Nov;88(11):1254-64

5. Tuomilehto J, Lindström J, Eriksson JG, Valle TT, Hämäläinen H, llanneParikka $\mathrm{P}$, et al. Prevention of type 2 diabetes mellitus by changes in lifestyle among subjects with impaired glucose tolerance. N Engl J Med. 2001 May 3;344:1343-50.

6. Nilsen V, Bakke PS, Gallefoss F. Effects of lifestyle intervention in persons at risk for type 2 diabetes mellitus - results from a randomised controlled trial. BMC Public Health. 2011 Nov 25;11:893.

7. Gunay T, Ulusel B, Velipasaoglu S, Unal B, Ucku R, Ozgener N. Factors affecting adult knowledge of diabetes in Narlidere health district, Turkey. Acta Diabetol. 2006;43:142-7.

8. Herman WH, Zimmet P. Type 2 diabetes: an epidemic requiring global attention and urgent action. Diabetes Care. 2012 May;35(5):943-4.

9. Foma MA, Saidu Y, Omoleke SA, Jafali J. Awareness of diabetes mellitus among diabetic patients in the Gambia: a strong case for health education and promotion. BMC Public Health. 2013 Dec 5;13:1124. intervention study to find the effect of health awareness on prevention of chronic disease like diabetes.

\section{ACKNOWLEDGEMENT}

We would like to thank all the participants for their invaluable information during the study.

\section{CONFLICT OF INTEREST}

We declare no conflict of interest in this study.

10. Muninarayana C, Balachandra G, Hiremath SG, Iyengar K, Anil NS. Prevalence and awareness regarding diabetes mellitus in rural Tamaka, Kolar. Int J Diabetes Dev Ctries. 2010 Jan;30(1):18-21.

11. Maina WK, Ndegwa ZM, Njenga EW, Muchemi EW. Knowledge, attitude and practices related to diabetes among community members in four provinces in Kenya: a cross-sectional study. Pan Afr Med J. 2010;7:15-8.

12. Ali RS, Fatemeh B, Mohammad A. People awareness about diabetes disease and its complications among aged 18 years and older in Bushehr port inhabitants (Iran). Diabetes \& Metabolic Syndrome: Clinical Research \& Reviews. 2007;1:245-9.

13. Deepa M, Bhansali A, Anjana RM, Pradeepa R, Joshi SR, Joshi PP, et al. Knowledge and awareness of diabetes in urban and rural India: the Indian council of medical research India diabetes study (phase I): Indian council of medical research India diabetes 4. Indian J Endocrinol Metab. 2014 May;18(3):379-85.

14. Murugesan N, Snehalatha C, Shobhana R, Roqlic G, Ramachandran A. Awareness about diabetes and its complications in the general and diabetic population in a city in southern India. Diabetes Res Clin Pract. 2007 Sep;77(3):433-7.

15. World Health Organisation. Action plan for the global strategy for the prevention and control of noncommunicable diseases 2008-2013; 2008. http://www.who.int/nmh/publications/9789241597418/en/. Accessed 4 Apr 2015.

16. He FJ, MacGregor GA. A comprehensive review on salt and health and current experience of worldwide salt reduction programmes. J Hum Hypertens.2009 Jun;23(6):363-84.

17. Stazzullo P, D'Elia L, Kandale NB, Cappuccio FP. Salt intake, stroke, and cardiovascular disease: meta-analysis of prospective studies. BMJ. 2009 Nov 29; 339: b4567" 